\title{
Particular qualities of wine grape varieties for high-quality varietal wine-making in conditions of the Krasnodar region*
}

\author{
Olga Sheludko**, Larisa Chemisova, Yuri Yakuba, Yekaterina Mitrofanova, \\ Anastasia Shirshova
}

Federal State Budget Scientific Institution "North Caucasian Federal Scientific Centre of Horticulture, Viticulture, Wine-making," 39 str. 40 Let Pobedy, Krasnodar, 350901, Russia

\begin{abstract}
Modern development of the Russian viticultural and winemaking industry is aimed at the production of competitive varietal premium wines. It is premised on acceleration of the breeding process of domestic wine grape varieties with the preset course of processing. The purpose of this workcк was to study the ratio between the most important quality components of the wines made from two classical and eight promising grape varieties domestic breeding (by Federal State Budget Scientific Institution "North Caucasian Federal Scientific Centre of Horticulture, Viticulture and Winemaking", hereafter - Institute) to determine the unique varietal particular qualities. The experiment was performed in 2013-2018. The grapes were picked from two plots located in the Central zone and in the Taman subzone, Krasnodar region. The red varietal wines were made according to the same technology and observing the same processing modes. The analytical research was performed repeatedly with qualification assessment of the results. Two-wayANOVA was used to identify the impact factors upon the wine components. As a result, the following appreciable grape varieties of the Institute's breeding were isolated, which demonstrated high accumulation of phenolic substances (over 3,000 mg/l) and anthocyanins (700-1100 mg/l) in wine: Vladimir, Granatovy, Kurchansky, Dmitri; the grape varieties with high accumulation of trans-resveratrol in wine: Vladimir $(4.7 \mathrm{mg} / \mathrm{l})$, Dmitri $(4.7 \mathrm{mg} / \mathrm{l})$, and Kurchansky $(3.0 \mathrm{mg} / \mathrm{l})$; the grape varieties for which wine the mass concentration of malic acid was by 2 to 2.5 times higher than the content of tartaric acid: Vladimir and Dmitri. It was shown that Antaris variety has low ecological plasticity and wine of this variety could be differ qualitatively depending upon edaphoclimatic conditions of the subzone.
\end{abstract}

\footnotetext{
* This research has been supported by the Kuban Scientific Fund, No. МФИ-20.1/21

** Corresponding author: scheludcko.olga@yandex.ru
} 


\section{Introduction}

Currently, the Russian winemaking industry undergoes the process of substantial changes related to the increased production volumes of Russian-made wines with protected geographical indication and protected appellation of origin; expansion of the assortment of premium varietal wines made from classical, autochthonal and domestically breeding grape varieties; development of high-quality and globally competitive winemaking [1-5]. The breeding process of domestic wine grape varieties specified usage direction must be further developed and accelerated to maintain the high speed of development of the national winemaking industry and lower its import dependency.

The challenges of breeding aimed at perfection of grape varieties meant for high-quality winemaking should allow for the anticipated trends related to climatic changes, increment of human-induced loads upon the environment, introduction of new highly promising technologies, and, consequently, production of a new generation of grape varieties and hybrids based on the established gene bank and gene collections that apart from being environmentally plastic, adapted to local agro-ecological conditions and giving high-quality yields, allow to craft competitive tailor-made wines [6-13].

High quality of a wine is caused by a well-balanced combination of carbohydrates, acids, phenolic compounds, flavour-forming components, integral characteristics, etc., that promote the exclusivity of the product's organoleptic perception [14-15]. Studies of qualitative characteristics of wines made from high-yielding grape varieties and identification of unique varietal peculiarities may become of great importance in the breeding process, and be of interest to study their DNA-profiles to choose the optimum marker system while identifying differences in different grape varieties. This is why the aim of the research was to study the ratios of main organic acids, mass concentration and alkalinity of ashes, the cationic contents of alkali and alkaline-earth metals and phenolic compounds, including anthocyanins and trans-resveratrol of wines made from classical and promising grape varieties Institute's breeding to ascertain the varietal particular qualities.

\section{Materials and methods}

The research objects were red dry wines made from eight wine grape varieties Institute's breeding: Antaris (Saperavi x Tsimlansky Cherny), Vladimir (Mitsar x Saperavi Severny), Granatovy (Saperavi x Cabernet Sauvignon), Dmitri (Varuset x Granatovy), Kurchansky (Muscat Kubansky x Saperavi Severny), Litdar (Khindogmy x Muscat Hamburg), Mitsar (Serkessiya x Cabernet Sauvignon), Satsimler (Saperavi x Tsimlansky Cherny), and as control - the European varieties: Cabernet Sauvignon and Merlot.

The grapes output yield in the agro-ecological conditions of the Central Zone of Krasnodar region (the city of Krasnodar; vinestock training - bilateral Cordon de Cazenave; planting system $-3.5 \times 2 \mathrm{~m}$ ) were harvested during technical maturity. The wines were made using the micro-winemaking techniques, according to the same pattern used to prepare dry red wines: temperature-controlled fermentation on marc with a 'floating cap' on one pure-culture yeast. For repeatability of the tests, no malolactic fermentation was performed. Upon completion of the fermentation process, the wines were taken off the lees. The wines were kept in $750 \mathrm{ml}$ glass bottles in conditions eliminating spoilage. The wines were studied after January 1 of the year following the vintage. The effects of varietal peculiarities upon the qualitative characteristics of red dry wines were studied from 2013 until 2018.

The specified physical and chemical parameters in the reviewed varietal wines were identified according to the standardized methods applicable in Russia. The amounts of organic acids, cations of alkali and alkaline-earth metals, and mass concentration of trans- 
resveratrol in the samples were determined by high-performance capillary electrophoresis on Kapel devices (Russia). The phenolic substances and anthocyanins were identified on a UNICO-1201 spectrophotometer. The measurements were preformed repeatedly with assessment of the results acceptability. Mathematical data treatment was conducted with the use of the Mathcad-15 software and Microsoft Excel 2019.

\section{Results and discussion}

At the first stage of the research, impact of the grape variety (factor A) and impact of the meteorological conditions of a year (factor B) upon the variance of the amounts of the total sum of phenolic substances, anthocyanins and organic acids were identified in the varietal wines with the help of 2-way-ANOVA (Table 1).

The assessment of homogeneity of the experimental results dispersion, and confirmation of dispersion balances were performed based on Cochran's criterion.

Table 1. Results of factor analysis of ANOVA

\begin{tabular}{|c|c|c|c|c|c|c|}
\hline $\begin{array}{c}\text { Source } \\
\text { of variance }\end{array}$ & $\begin{array}{c}\text { Sum } \\
\text { of squares }\end{array}$ & $\begin{array}{l}\text { Degree } \\
\text { of freedom }\end{array}$ & $\begin{array}{c}\text { Mean } \\
\text { square } \\
\text { (variance } \\
\text { estimate) }\end{array}$ & F deviation & F critical & $\begin{array}{c}\text { Comments } \\
\text { at } 95 \% \\
\text { probability } \\
\text { level }\end{array}$ \\
\hline \multicolumn{7}{|c|}{ Total sum of phenolic substances } \\
\hline Variety & 15731444 & 9 & 1747938 & 17.612 & 2.096 & affects \\
\hline Year & 409223.8 & 5 & 81844.75 & 0.825 & 2.422 & $\begin{array}{c}\text { does not } \\
\text { affect }\end{array}$ \\
\hline Error & 4466114 & 45 & 99246.97 & & & \\
\hline Total & 20606781 & 59 & & & & \\
\hline \multicolumn{7}{|c|}{ Anthocyanins } \\
\hline Variety & 7647962 & 9 & 849773.5 & 7.758 & 2.097 & affects \\
\hline Year & 574039.2 & 5 & 114807.8 & 1.048 & 2.422 & $\begin{array}{l}\text { does not } \\
\text { affect }\end{array}$ \\
\hline Error & 4928964 & 45 & 109532.5 & & & \\
\hline Total & 13150965 & 59 & & & & \\
\hline \multicolumn{7}{|c|}{ Total sum of organic acids } \\
\hline Variety & 33.996 & 9 & 3.777 & 94.134 & 2.096 & affects \\
\hline Year & 0.4296 & 5 & 0.08592 & 2.141 & 2.422 & $\begin{array}{c}\text { does not } \\
\text { affect }\end{array}$ \\
\hline Error & 1.805733 & 45 & 0.040127 & & & \\
\hline Total & 36,23136 & 59 & & & & \\
\hline
\end{tabular}

The performed analysis showed that it was the varietal peculiarities of the grapes that affected considerably the analyzed wine quality indicators. As for the year conditions, their impact was insignificant throughout the period of research.

The established regularity allowed to confirm the ability of the reviewed grape varieties to preserve the quality of the wine caused by varietal peculiarities irrespective of the vintage year.

At the second stage of the study, conformance audit of the varietal wines was performed with regard to the requirements established in Russia, and contribution of the soil and climatic conditions of the given viticultural subzone to the changes in the amounts of phenolic substances, including anthocyanins and organic acids, mass concentration and alkalinity of ashes, cationic contents of alkali and alkaline-earth metals was identified with due account of the grape variety (Tables $2,3,4$ ). 
It was ascertained that the specified physical and chemical parameters of all varietal wines under study complied with the requirements established for this wine category by Russian law.

The analysis of phenolic compounds in the studied varietal wines demonstrated (Table 2) that the amounts of both the total sum of phenolic substances and of anthocyanins in the reviewed wines made from grape varieties grown in the soil and climatic conditions of the Central Zone of Krasnodar region were higher than in the wines from grapes grown in the Taman Subzone. The wines crafted from such grape varieties as Vladimir, Granatovy, Kurchansky, Dmitri were distinguished by a high accumulation of phenolic substances $(\sim 3000 \mathrm{mg} / \mathrm{l})$. In the varietal wines Antaris and Mitsar, the amount of phenolic substances was at the level of the control sample, Cabernet Sauvignon $(\sim 2000 \mathrm{mg} / \mathrm{l})$.

The amounts of the total sum of phenolic substances in varietal wines varied subject to the unique peculiarities of the subzone, from $0.6 \%$ (Mitsar) to $17 \%$ (Antaris). The maximum difference in the amount of phenolic substances depending on the soil and climatic conditions was observed in Antaris grape (17\%) and in the control West European Cabernet Sauvignon (16\%) and Merlot (12.4\%) grapes.

Table 2. Amounts of phenolic substances in red varietal wine, $\mathrm{mg} / \mathrm{l}$ (average figures for 2013-2018)

\begin{tabular}{|c|c|c|c|c|c|c|c|c|c|c|}
\hline \multirow{2}{*}{$\begin{array}{c}\text { Grape } \\
\text { variety }\end{array}$} & \multicolumn{2}{|c|}{$\begin{array}{c}\text { Total sum } \\
\text { of phenolic } \\
\text { substances }\end{array}$} & \multicolumn{2}{|c|}{ Monomers } & \multicolumn{2}{|c|}{ Polymers } & \multicolumn{2}{c|}{ Anthocyanins } & \multicolumn{2}{|c|}{$\begin{array}{c}\text { Trans- } \\
\text { resveratrol }\end{array}$} \\
\cline { 2 - 13 } & CZ & TSZ & CZ & TSZ & CZ & TSZ & CZ & TSZ & CZ & TSZ \\
\hline Antaris & 2300 & 1900 & 750 & 700 & 1550 & 1200 & 465 & 330 & 1.0 & 1.0 \\
\hline Vladimir & 3600 & 3540 & 1320 & 1300 & 2280 & 2240 & 1090 & 950 & 4.7 & 4.7 \\
\hline Granatovy & 3100 & 2890 & 1450 & 1140 & 1650 & 1750 & 1120 & 1005 & 2.1 & 2.2 \\
\hline Dmitri & 2800 & 2680 & 870 & 860 & 1930 & 1820 & 735 & 720 & 4.7 & 4.7 \\
\hline Kurchansky & 3000 & 2870 & 1000 & 930 & 2000 & 800 & 1200 & 1085 & 3.0 & 3.0 \\
\hline Litdar & 1715 & 1705 & 660 & 635 & 1055 & 1070 & 260 & 250 & 0.8 & 0.9 \\
\hline Mitsar & 2100 & 1900 & 900 & 750 & 1200 & 1150 & 300 & 280 & 0.9 & 0.9 \\
\hline Satsimler & 2640 & 2600 & 820 & 780 & 1820 & 1820 & 360 & 345 & 1.0 & 1.0 \\
\hline $\begin{array}{c}\text { Cabernet } \\
\text { Sauvignon }\end{array}$ & 2080 & 1750 & 720 & 580 & 1360 & 1170 & 295 & 235 & 1.7 & 1.6 \\
\hline Merlot & 1940 & 1700 & 700 & 600 & 1240 & 1100 & 250 & 240 & 2.1 & 2.1 \\
\hline
\end{tabular}

$\mathrm{CZ}$ - Central Zone, Krasnodar region; TSZ - Taman Subzone, Krasnodar region

The mass concentrations of anthocyanins varied in the studied varietal wines from 1200 $\mathrm{mg} / \mathrm{l}$ (Kurchansky) down to $250 \mathrm{mg} / \mathrm{l}$ (Merlot) (Table 2). High amount of anthocyanins was observed for such varietal wines as Kurchansky, Granatovy, Vladimir, and Dmitri. As for Satsimler, Mitsar and Litdar wines, the amount of anthocyanins there was at a level of the control Cabernet Sauvignon and Merlot.

It was ascertained that the subzone significantly affected the amount of anthocyanins in the studied varietal wines. The mass concentrations of anthocyanins varied, depending upon vine growing conditions, from 29\% (Antaris) to 2\% (Dmitri). High impact of the subzone's soil and climatic conditions upon the amount of anthocyanins was established for Antaris (29\%), Cabernet Sauvignon (20.3\%), and Granatovy (18.3\%); insignificant impact was observed for Dmitri (2\%), Litdar (3.8\%), and Satsimler (4.2\%).

It is worth noting that the mass concentration of such biologically valuable substance as trans-resveratrol changed in the varietal wines subject to the grapevine growing conditions at a level of measurement uncertainty. Say, in the wines made from Vladimir, Dmitri and Kurchansky grapes its content was 1.5 to 2.5 times higher than in the control samples from Cabernet Sauvignon and Merlot. 
The analysis of the amounts of organic acids in the varietal wines under review showed that the soil and climatic conditions of the grapevine habitat had the opposite effect as compared with the accumulation of phenolic substances (Table 3). In all reviewed varietal wines crafted from grapes grown in the Taman Subzone of Krasnodar region, the amounts of organic substances were higher than in the wines from grapes grown in the Central Zone of Krasnodar region. The maximum difference was observed for Antaris grape (12.6\%). High differences in the total sum of organic acids was observed for the wines made from Kurchansky (10.3\%), Litdar (9.3\%), Mitsar (8.4\%), and Merlot (8.2\%). The difference between the total amount of organic acids in the Granatovy wine subject to the subzone was the least compared to the other varietal wines, and equaled to $2.5 \%$. The mean difference between the amount of organic acids in the varietal wines from the Central Zone and the Taman Subzone of Krasnodar region was observed for such grape varieties as Vladimir (6.1\%), Cabernet Sauvignon (6.5\%) and Dmitri (5.1\%).

A significant excess of the mass concentrations of malic acid over tartaric acid (up to 1.5-2 times) was noted for the varietal wines from Vladimir and Dmitri grapes. For Satsimler wine, high accumulation of citric acid $(1.0 \mathrm{mg} / \mathrm{l})$ was established.

Table 3. Amounts of organic acids in red varietal dry wines, $g / 1$ (average figures for 2013-2018)

\begin{tabular}{|c|c|c|c|c|c|c|c|c|c|c|c|c|c|c|}
\hline \multirow{2}{*}{$\begin{array}{c}\text { Grape } \\
\text { variety }\end{array}$} & \multicolumn{2}{|c|}{ Tartaric } & \multicolumn{2}{|c|}{ Malic } & \multicolumn{2}{c|}{ Succinic } & \multicolumn{2}{c|}{ Citric } & \multicolumn{2}{|c|}{ Acetic } & \multicolumn{2}{|c|}{ Lactic } & \multicolumn{2}{c|}{ Sum } \\
\cline { 2 - 18 } & CZ & TSZ & CZ & TSZ & CZ & TSZ & CZ & TSZ & CZ & TSZ & CZ & TSZ & CZ & TSZ \\
\hline Antaris & 2.8 & 3.0 & 2.7 & 2.9 & 1.1 & 1.3 & 0.4 & 0.4 & 0.4 & 0.4 & 0.2 & 0.1 & 7.6 & 8.7 \\
\hline Vladimir & 1.6 & 1.7 & 4.0 & 4.5 & 1.0 & 1.0 & 0.6 & 0.6 & 0.3 & 0.2 & 0.2 & 0.2 & 7.7 & 8.2 \\
\hline Granatovy & 3.0 & 3.1 & 2.9 & 3.0 & 0.8 & 0.9 & 0.6 & 0.5 & 0.4 & 0.4 & 0.2 & 0.2 & 7.9 & 8.1 \\
\hline Dmitri & 2.0 & 2.0 & 3.3 & 3.6 & 0.9 & 1.2 & 0.6 & 0.5 & 0.4 & 0.4 & 0.2 & 0.1 & 7.4 & 7.8 \\
\hline Kurchansky & 1.8 & 1.9 & 2.5 & 3.0 & 0.8 & 1.0 & 0.6 & 0.5 & 0.2 & 0.2 & 0.2 & 0.2 & 6.1 & 6.8 \\
\hline Litdar & 3.0 & 3.4 & 3.0 & 3.0 & 0.8 & 1.1 & 0.5 & 0.6 & 0.3 & 0.3 & 0.2 & 0.2 & 7.8 & 8.6 \\
\hline Mitsar & 2.7 & 2.9 & 2.8 & 3.1 & 0.9 & 1.1 & 0.5 & 0.5 & 0.4 & 0.5 & 0.3 & 0.2 & 7.6 & 8.3 \\
\hline Satsimler & 2.3 & 2.4 & 3.1 & 3.4 & 1.2 & 1.4 & 1.0 & 1.0 & 0.6 & 0.6 & 0.2 & 0.3 & 8.4 & 9.1 \\
\hline $\begin{array}{c}\text { Cabernet } \\
\text { Sauvignon }\end{array}$ & 2.9 & 3.1 & 2.2 & 2.3 & 1.1 & 1.3 & 0.4 & 0.4 & 0.4 & 0.4 & 0.2 & 0.2 & 7.2 & 8.1 \\
\hline Merlot & 2.6 & 2.8 & 1.6 & 1.7 & 0.6 & 0.6 & 0.3 & 0.2 & 0.4 & 0.4 & 0.2 & 0.3 & 5.6 & 6.0 \\
\hline
\end{tabular}

By analyzing the mass concentrations of ash, its alkalinity and amount of alkali and alkaline-earth metals in the varietal wines understudy, it was ascertained that the peculiarities of the subzone did not affected significantly the mass concentration of ash and its alkalinity, or the amount of individual cations of alkali and alkaline-earth metals (Table 4). Their amounts in the wines under review, depending upon the soil and climatic conditions of the subzone, varied in direct ratio to the changes in the amount of tartaric acid. This was caused by the fact that the saline constituent of total acidity of wines is first of all represented by salts of tartaric acid being the strongest organic acid presented in wine. 
Table 4. Amounts of alkali and alkaline-earth metals in red varietal dry wines, $\mathrm{mg} / \mathrm{l}$ for mass concentration of ash, $\mathrm{g} / \mathrm{l}$ for ash alkalinity, $\mathrm{NaOH}$ mg-equivalents/1 (average figures for 2013-2018)

\begin{tabular}{|c|c|c|c|c|c|c|c|c|c|c|c|c|}
\hline \multirow{2}{*}{$\begin{array}{l}\text { Grape } \\
\text { variety }\end{array}$} & \multicolumn{2}{|c|}{ Potassium } & \multicolumn{2}{|c|}{ Sodium } & \multicolumn{2}{|c|}{ Magnesium } & \multicolumn{2}{|c|}{ Calcium } & \multicolumn{2}{|c|}{ Ashes } & \multicolumn{2}{|c|}{$\begin{array}{c}\text { Ash } \\
\text { alkalinity }\end{array}$} \\
\hline & $\mathrm{CZ}$ & TSZ & $\mathrm{CZ}$ & TSZ & $\mathrm{CZ}$ & TSZ & $\mathrm{CZ}$ & TSZ & $\mathrm{CZ}$ & TSZ & $\mathrm{CZ}$ & TSZ \\
\hline Antaris & 905 & 915 & 88 & 90 & 65 & 60 & 85 & 85 & 2.1 & 2.1 & 33.0 & 32.5 \\
\hline Vladimir & 910 & 940 & 45 & 50 & 80 & 100 & 90 & 105 & 2.0 & 2.0 & 32.0 & 34.5 \\
\hline Granatovy & 1000 & 1040 & 45 & 45 & 60 & 70 & 85 & 85 & 2.9 & 2.9 & 33.6 & 35.0 \\
\hline Dmitri & 900 & 920 & 60 & 60 & 60 & 65 & 80 & 80 & 2.0 & 2.0 & 31.5 & 32.0 \\
\hline Kurchansky & 930 & 950 & 60 & 65 & 70 & 75 & 50 & 50 & 2.0 & 2.0 & 31.0 & 32.0 \\
\hline Litdar & 940 & 950 & 40 & 40 & 40 & 40 & 50 & 50 & 2.4 & 2.4 & 29.5 & 30.0 \\
\hline Mitsar & 885 & 900 & 45 & 50 & 55 & 60 & 60 & 75 & 1.8 & 1.9 & 29.0 & 31.0 \\
\hline Satsimler & 1100 & 1190 & 50 & 50 & 55 & 60 & 75 & 85 & 2.3 & 2.4 & 36.0 & 38.5 \\
\hline $\begin{array}{l}\text { Cabernet } \\
\text { Sauvignon }\end{array}$ & 890 & 900 & 35 & 35 & 40 & 45 & 80 & 95 & 1.8 & 1.8 & 29.5 & 30.5 \\
\hline Merlot & 950 & 950 & 55 & 60 & 75 & 85 & 45 & 50 & 2.0 & 2.0 & 31.0 & 32.0 \\
\hline
\end{tabular}

\section{Conclusion}

It was ascertained that the maximum contribution to the changes in the amounts of wine quality forming compounds (organic acids, phenolic compounds including anthocyanins, cations of alkali, alkaline-earth metals, and resveratrol) was made by the varietal peculiarities of grapes.

The following grape varieties selected by the Institute and providing for high accumulation of phenolic substances and anthocyanins in wine were singled out: Vladimir, Granatovy, Kurchansky, and Dmitri.

It was determined that the impact of the soil and climatic conditions of the subzone upon changes in the concentrations of phenolic substances and anthocyanins in red varietal wines equals to $17 \%$ and $27 \%$, correspondingly.

It was noted that accumulation of trans-reveratrol in the red wines under study was related to the varietal features of the grapes and is not related to the grapevine habitat. The following grape varieties with high accumulation of trans-resveratrol in wine were distinguished: Vladimir, Dmitri, and Kurchansky.

It was established that the amounts of main organic acids in the red varietal wines under study depended upon the grape variety and habitat, while the amount of individual tartaric acid, as well as the saline part of acids changed only insignificantly depending the soil and climatic conditions of the subzone. The following grape varieties characterized by significant excess of the mass concentration of malic acid over tartaric acid were noted: Vladimir, and Dmitri.

It was ascertained that wine crafted from Satsimler grapes accumulated high concentrations of citric acid $(1.0 \mathrm{~g} / \mathrm{l})$.

It was noted that Antaris wine, depending on the soil and climatic conditions of the subzone, differed substantially by the amount of the total sum of phenolic compounds $(17 \%)$, anthocyanins $(27 \%)$, and organic acids (12.6\%), which fact lets us make a conclusion that this grape variety has low ecological plasticity. 


\section{References}

1. O. A. Chursina, V. A. Zagoruiko, L. A. Legasheva, L. M. Solovyova, E. L. Udod, A. E. Soloviev, A. V. Martynovskaya, Magarach. Viticulture and Winemaking, 22(1), 63-72 (2020). https://doi.org/10.35547/IM.2020.22.1.013.

2. F. Terribileab, A. Bonfantec, A. D'Antonioe, R. De Mascellisc, C. De Micheled, G. Langellac, P. Mannac, F. A. Miletia, S. Vingiania, A. Basile, Comput Electron Agr, 140, 88-102 (2017). http://dx.doi.org/10.1016/j.compag.2017.05.028.

3. I. Feher, D.A. Magdas, A. Dehelean, C. Sbrbu, Food Sci Technol, 56, 5225-5233 (2019). https://link.springer.com/article/10.1007/s13197-019-03991-4.

4. M. Agostino, F. Trivieri, Food Policy, 46, 22-36 (2014). http://dx.doi.org/ 10.1016/j.foodpol.2014.02.002.

5. P. Lock, S. Mounter, E. Fleming, J. Moss, Wine Econ Policy, 8, 180-190 (2019). https://doi.org/10.1016/j.wep.2019.10.002.

6. O. Ashenfelter, K. Storchmanny, Rev Environ Econ Policy, 10(1), 25-46 (2016). https://doi.org/10.1093/REEP/REV018.

7. A. Bonfantea, E. Monacoa, G. Langellaa, P. Mercoglianode, E. Bucchignanide, P. Mannaa, F. Terribileb, Sci Total Environ, 624, 294-308 (2018) https://doi.org/ 10.1016/j.scitotenv.2017.12.035.

8. M. Gutiŭrreza, C. Domingob, J. Vila-Planasa, A. Ipatova, F. Capdevilab, S. Demmingc, S. Bьttgenbachc, A. Lloberaa, C. Jimŭnez-Jorqueraa, Sens Actuators B Chem, 156(2), 695-702 (2011). https://doi.org/10.1016/j.snb.2011.02.020.

9. J. E. Welke, V. Manfroi, M. Zanus, M. Lazzarotto, C. Alcaraz Zini, Food Chem, 141(4), 3897-3905 (2013). https://doi.org/10.1016/j.foodchem.2013.06.100.

10. B. Stanimirović, J. Popović Djordjević, B. Pejin, R. Maletić, h. Tešić, Scientia Hortic, 237, 74-80 (2018). https://doi.org/10.1016/j.scienta.2018.03.043.

11. H. Hannin, Acta Hortic. 1248, 1-6 (2019). https://doi.org/10.17660/ActaHortic. 2019.1248.1.

12. S. Foria, C. Monte, R. Testolin, G. Di Gaspero, G. Cipriani, Acta Hortic, 1248, 549-554 (2019). https://doi.org/10.17660/ActaHortic.2019.1248.73.

13. O. N. Sheludko, T. I. Guguchkina, N. K. Strizhov, Fruit growing and viticulture of South Russia, 38 (2), 75-85 (2016) http://journalkubansad.ru/pdf/16/02/07.pdf.

14. P. R. Duchowicza, M. A. Giraudob, E. A. Castroa, A. B. Pomilioc, Food Chem, 140 (1-2), 210-216 (2013) https://doi.org/10.1016/j.foodchem.2013.02.064.

15. F. Foroni, M. Vignando, M. Aiello, V. Parma, R. I. Rumiati, Food Qual Prefer, 58, 18-23 (2017) https://doi.org/10.1016/j.foodqual.2016.12.012. 